\title{
Pengaruh Pemberian Tanaman Obat Sebagai Feed Additive Dalam Ransum Terhadap Performa dan Organ Pencernaan Ayam Pedaging
}

\section{The Effect of Giving Medicinal Plant As An Additive Feed In The Rations on Performance and Digestive Organs Broiler}

\author{
Yurni Sari Amir ${ }^{* 1)}$, Prima Silvia Noor ${ }^{1)}$, Sujatmiko ${ }^{1)}$, Nelzi Fati ${ }^{2)}$, Toni Malvin ${ }^{2)}$ \\ ${ }^{1}$ Program Studi Pamedik Veteriner, Politeknik Pertanian Negeri Payakumbuh \\ ${ }^{2}$ Program Studi Budi Daya Ternak, Politeknik Pertanian Negeri Payakumbuh \\ *yurnisariamir@gmail.com
}

$\begin{array}{ll}\text { Diterima } & : 24 \text { Agustus 2020 } \\ \text { Disetujui } & : 29 \text { Agustus 2020 } \\ \text { Diterbitkan } & : 31 \text { Agustus 2020 }\end{array}$

Abstrak: Tujuan penelitian adalah untuk mengetahui efek pemberian tanaman obat sebagai feed additive di dalam ransum terhadap performa dan organ pencernaan ayam pedaging. Penelitian dilakukan selama 2 bulan, di Laboratorium Nutrisi dan Pakan Ternak dan di kandang ayam pedaging Laboratorium Produksi Ternak, Politeknik Pertanian Negeri Payakumbuh. Metode yang digunakan adalah eksperimen dengan Rancangan Acak Lengkap yang menggunakan 100 ekor ayam pedaging umur satu hari, 5 perlakuan dan 4 ulangan, masing-masing perlakuan dipelihara selama 30 hari. Ransum yang diberikan adalah ransum basal yang terdiri dari jagung, bungkil kedele, tepung ikan, tepung mie, minyak dan top mix. Perlakuan pada penelitian ini yaitu ransum adukan $100 \%$ sebagai kontrol (A), penambahan 0,5\% tepung daun salam (B), penambahan 0,5\% tepung daun pepaya $(C)$, penambahan $0,5 \%$ tepung daun jambu biji (D) dan penambahan $0,5 \%$ tepung daun miana (E). Variabel yang diukur adalah konsumsi ransum, pertambahan bobot badan, konversi ransum, persentase bobot proventiculus dan persentase bobot ventriculus. Hasil penelitian didapatkan bahwa pemberian tepung daun dalam ransum memberikan pengaruh yang tidak berbeda nyata $(P>0,05)$ terhadap konsumsi ransum, pertambahan bobot badan, konversi ransum, persentase bobot proventriculus dan ventriculus. Kesimpulan penelitian ini adalah pemberian tanaman obat sebagai feed additive sebanyak 0,5\% dalam ransum tidak memberikan efek negatif terhadap performa dan organ pencernaan ayam pedaging .

Kata Kunci: Tepung daun salam, daun pepaya, daun jambu biji, daun miana, pertambahan bobot badan

Abstract: The research objective was to determine the effect of giving medicinal plants as feed additives in the ration on the performance and digestive organs of broilers. The research was conducted for 2 months, in the Laboratory of Animal Nutrition and Feed and in the broilers cage of the Animal Production Laboratory, Payakumbuh State Agricultural Polytechnic. The method used was an experiment with a completely randomized design using 100 broilers aged one day, 5 treatments and 4 replications, each treatment was maintained for 30 days. The rations given were basal rations consisting of corn, soybean meal, fish meal, noodle flour, oil and top mix. The treatments in this study were $100 \%$ mix ration as control (A), addition of $0.5 \%$ bay leaf flour (B), addition of $0.5 \%$ papaya leaf flour $(C)$, addition of $0.5 \%$ guava leaf flour $(D)$ and addition of $0.5 \%$ miana leaf flour $(E)$. The variable measured were ration consumption, body weight gain, ration conversion, percentage of proventiculus weight and percentage of ventricular weight. The results showed that giving leafflour in the ration had no significant effect $(P>$ 0.05) on ration consumption, body weight gain, ration conversion, proventriculus and ventriculus weight percentage. The conclusion of this study is that the provision of medicinal plants as feed additives as much as $0.5 \%$ in the ration did not have a negative effect on the performance and digestive organs of broilers.

Keywords: $\quad$ Bay leafflour, papaya leaves, guava leaves, miana leaves, weight gain 


\section{Pendahuluan}

Penyediaan bahan pangan yang aman, sehat, utuh dan halal merupakan sebuah kebutuhan bagi konsumen, karena telah mulai meningkatnya kesadaran gizi dan pengetahuan masyarakat akan bahan pangan yang aman, sehat, utuh dan halal untuk dikonsumsi. Daging ayam termasuk bahan pangan sumber protein hewani yang sangat disukai oleh masyarakat.

Pemberian pakan yang berkualitas dengan kecukupan nutrisinya dalam pemeliharaan ayam pedaging haruslah diperhatikan agar pertumbuhan dan produksi ayam pedaging maksimal. Selain dari pada itu upaya pencegahan penyakit juga harus dilakukan agar tidak terjadinya penyebaran penyakit yang menyebabkan tingginya angka mortalitas. Sehingga perlu usaha untuk pencegahan penyakit pada ayam pedaging, selain dari pada memperhatikan sanitasi kandang adalah dengan vaksinasi dan pemberian obat-obatan yang dikenal dengan antibiotik. Antibiotik merupakan jenis obat-obatan yang ditambahkan peternak dalam pemeliharaan ayam pedaging dengan tujuan untuk peningkatan efisiensi pakan, peningkatan produksi dan menjaga kesehatan yang dikenal dengan istilah Antibiotic Growth Promotor (AGP). Pemanfaatan AGP sebagai feed additive dapat mempercepat pertumbuhan ayam pedaging dan mencegah penyakit sehingga menekan angka mortalitas.

Pemberian obat-obatan berupa antibiotik pada waktu yang lama dikhawatirkan akan meninggalkan residu pada daging ayam pedaging. Oleh karena itu perlu pemanfaatan tanaman obat sebagai alternatif pengganti dari obat-obatan sintetik. Ada beberapa jenis tanaman yang sudah biasa digunakan oleh orang-orang tua kita sebagai obat karena khasiatnya yang terkandung pada tanaman tersebut. Diantaranya adalah daun salam, daun pepaya, daun jambu biji dan daun miana.

Daun salam biasa digunakan sebagai bumbu masakan. Kandungan pada daun salam berupa minyak atsiri yang bersifat antibakteri, tanin bersifat menciutkan (astringent). Daun salam juga berkhasiat untuk obat sakit perut [1]. Tepung daun salam yang diberikan sampai level $3 \%$ dapat menurunkan populasi bakteri $E$ coli dan menekan angka kematian ayam pedaging [2]. Pepaya merupakan tanaman yang mudah didapatkan, daun pepaya bisa digunakan sebagai sayuran yang dikonsumsi. Daun pepaya juga memiliki khasiat sebagai tanaman obat. Tanin, alkaloid, flavonoid, steroid, dan saponin merupakan senyawa aktif yang terdapat dalam daun pepaya. Aktivitas antibakteri dimiliki oleh senyawa aktif alkaloid dari ekstrak etanol daun pepaya [3]. Daun jambu biji bermanfaat sebagai antidiare, antiinflamasi dan antimutagenik [4]. Miana berperan menyembuhkan beberapa penyakit karena aktivitas farmakologis dari kandungan zat fitokimianya yaitu adanya tanin, flavonoid,steroid, saponin, eugenol, fitol, streptozocin, quersetin, asam rosmanik dan minyak atsiri [5].

Berdasarkan kandungan senyawa aktif dan kegunaannya sebagai tanaman obat, maka dilakukan penelitian dengan judul "Pengaruh Pemberian Tanaman Obat Sebagai Feed Additive dalam Ransum Terhadap Performa dan Organ Pencernaan Ayam Pedaging".

\section{Materi dan Metoda}

Penelitian ini dilakukan di Laboratorium Nutrisi dan Pakan Ternak dan kandang ayam pedaging Laboratorium Produksi Ternak Politeknik Pertanian Negeri Payakumbuh selama 2 (dua) bulan. Persiapan tepung daun sebagai feed additive dan pemeliharaan ayam pedaging serta pengamatan selama 30 hari.

Alat yang digunakan adalah berupa blender, kandang beserta perlengkapannya dan timbangan untuk penimbangan pakan dan bobot ayam. Kandang yang digunakan sistem litter dengan ukuran per unit adalah 50 x $50 \mathrm{~cm}$ dan tinggi sekat $60 \mathrm{~cm}$. Kandang dibuat sebanyak 20 unit yang masing-masing unit diisi 5 ekor. Bahan yang digunakan adalah DOC sebanyak 100 ekor, bahan pakan terdiri dari jagung, tepung mie, bungkil kedele, tepung ikan, minyak, top mix dan tanaman obat yang terdiri dari tepung daun salam (Eugenia polyantha Wight), daun pepaya (Carica pepaya Linn), daun jambu biji (Psidium quava $L$ ) dan tepung daun miana (Coleus scutellarioides).

Tahapan dalam pelaksanaan penelitian ini diawali dengan pembuatan tepung daun sebagai feed additive, yaitu dengan mengumpulkan daun salam, daun pepaya, daun jambu biji dan daun miana. Masing-masing daun dikeringkan di bawah sinar matahari, setelah kering daun tersebut dilanjutkan dengan menghaluskannya menjadi tepung. Pembuatan tepung dengan menggunakan alat berupa blender. Setelah proses pemblenderan hingga halus menjadi tepung, maka tepung daun tersebut siap digunakan sebagai feed additive dengan dosis o,5 \% dari jumlah ransum. Pemberian tepung daun dimulai saat ayam berumur 8 hari. Pada ayam pedaging umur 1 hari sampai 7 hari, ransum yang diberikan adalah ransum komersial. Pemberian ransum adukan dengan penambahan tepung daun tanaman obat diberikan secara bertahap yaitu pada hari ke-8 diberikan $75 \%$ ransum komersial dan $25 \%$ ransum adukan. Pada hari ke-9 dilanjutkan pemberian ransum dengan perbandingan 50\% : 50\% ransum komersial dan ransum adukan. Pada hari ke-10 ransum yang diberikan adalah 25\% : 75\% ransum komersial dan ransum adukan. Pada hari ke-11 sampai hari ke-30, ransum yang diberikan adalah 100\% ransum adukan dengan penambahan tepung daun tanaman obat. 
Rancangan yang digunakan pada penelitian ini adalah Rancangan Acak Lengkap (RAL) dengan 5 perlakuan dan 4 ulangan, yaitu:

$\mathrm{A}=$ Ransum adukan

$\mathrm{B}=$ Ransum adukan $+0,5 \%$ tepung daun salam

$\mathrm{C}=$ Ransum adukan $+0,5 \%$ tepung daun pepaya

$\mathrm{D}=$ Ransum adukan $+0,5 \%$ tepung daun jambu biji

$\mathrm{E}=$ Ransum adukan $+0,5 \%$ tepung daun miana lain:

Variabel yang diukur selama penelitian antara

\section{a) Konsumsi ransum}

Nilai konsumsi ransum didapatkan dari jumlah ransum yang disediakan dikurangi dengan sisa ransum. Konsumsi ransum dihitung secara berkala setiap minggunya.

b) Pertambahan bobot badan

Nilai pertambahan bobot badan didapatkan dari timbangan bobot badan secara berkala setiap minggunya, yaitu bobot badan ayam pada minggu tertentu dikurangi dengan bobot badan ayam minggu sebelumnya.

\section{c) Konversi ransum}

Nilai konversi ransum didapatkan dari perbandingan jumlah ransum terkonsumsi dengan pertambahan bobot badan.

d) Persentase bobot proventriculus

Nilai persentase bobot proventriculus dihitung berdasarkan perbandingan bobot proventriculus dengan bobot hidup dan dikalikan $100 \%$

e) Persentase bobot ventriculus

Nilai persentase bobot pventriculus dihitung berdasarkan perbandingan bobot ventriculus dengan bobot hidup dan dikalikan $100 \%$

Data yang didapatkan dari hasil pengamatan selama penelitian, diuji dengan menggunakan analisis keragaman. Apabila didapatkan hasil perbedaan nyata $(\mathrm{P}<0.05)$ antar perlakuan, maka dilanjutkan dengan uji jarak berganda Duncan's New Multiple Range Test [6]

Tabel 1. Komposisi dan kandungan nutrisi untuk ransum ayam pedaging

\begin{tabular}{|c|c|c|c|c|c|c|}
\hline No & Bahan pakan & $\begin{array}{c}\text { Formulasi } \\
(\%)\end{array}$ & $\begin{array}{l}\text { PK } \\
(\%)\end{array}$ & $\begin{array}{c}\text { EM }^{*} \\
\text { (Kkal/Kg) }\end{array}$ & $\begin{array}{l}\text { SK } \\
(\%)\end{array}$ & $\begin{array}{l}\text { LK } \\
(\%)\end{array}$ \\
\hline 1. & Jagung & 48,5 & 4,64 & 1629.6 & 0,49 & 2,27 \\
\hline 2. & Bungkil kedele & 40 & 16,15 & 896 & 2,12 & 1,63 \\
\hline 3. & Tepung ikan & 3 & 1,16 & 92.4 & 0,37 & 0,03 \\
\hline 4. & Tepung mie & 5 & 0,52 & 182.5 & 0,15 & $\mathrm{o}$ \\
\hline 5. & Minyak nabati & 3 & o & 258 & o & o \\
\hline \multirow[t]{2}{*}{6.} & Top mix & 0,5 & o & & o & o \\
\hline & & 100 & 22,47 & 3058.50 & 3,12 & 3,94 \\
\hline
\end{tabular}

Keterangan : Hasil analisis proksimat labor kimia Politeknik Pertanian Negeri Payakumbuh (2019)

Hasil perhitungan EM berdasarkan tabel komposisi zat-zat makanan dalam bahan pakan untuk unggas [7] dan [8].

\section{Hasil dan Pembahasan}

Hasil pengamatan selama penelitian pada ayam pedaging dari pengaruh pemberian tanaman obat berupa tepung daun sebagai feed additive dalam ransum terhadap konsumsi ransum, pertambahan bobot badan dan konversi ransum disajikan pada Tabel 2.

Tabel 2. Rataan konsumsi ransum, pertambahan bobot badan, konversi ransum, persentase bobot proventriculus dan ventriculus ayam pedaging

\begin{tabular}{lccccc}
\hline \multirow{2}{*}{\multicolumn{1}{c}{ Pengamatan }} & \multicolumn{5}{c}{ Perlakuan } \\
\cline { 2 - 6 } & A & B & C & D & E \\
\hline Konsumsi ransum (g/ekor/) & 2295,28 & 2306,58 & 2386,31 & 2238,78 & 2283,85 \\
Pertambahan bobot badan (g/ekor) & 1121,32 & 1136,09 & 1203,23 & 1197,48 & 1204,53 \\
Konversi ransum & 2,05 & 2,03 & 1.98 & 1,87 & 1,90 \\
Bobot proventriculus (\%) & 0,664 & 0,601 & 0,511 & 0,628 & 0,555 \\
Bobot ventriculus (\%) & 2,086 & 1,779 & 1,801 & 2,181 & 2,038 \\
\hline
\end{tabular}

\subsection{Konsumsi ransum}

Berdasarkan hasil analisis keragaman pada Tabel 2 diketahui bahwa pemberian tepung daun tanaman obat sebagai feed additive pada ransum tidak memberikan pengaruh yang berbeda nyata $(\mathrm{P}>0,0,5)$ terhadap konsumsi ransum. Tidak berbeda nyatanya pengaruh pemberian tepung daun salam, pepaya, jambu biji, tepung daun miana dan juga pada ransum tanpa pemberian tepung daun terhadap konsumsi ransum dikarenakan penggunaannya pada taraf yang rendah yaitu $0,5 \%$ dari jumlah ransum. Penambahan 
tepung daun pada taraf $0,5 \%$ ke dalam ransum tidak terlalu banyak mempengaruhi kualitas kandungan nutrisi ransum dan palatabilitas ransum yang akan berdampak terhadap konsumsi ransum. Grafik penambahan tepung daun sebagai feed additive selama penelitian terhadap konsumsi ransum seperti terlihat pada Gambar 1.

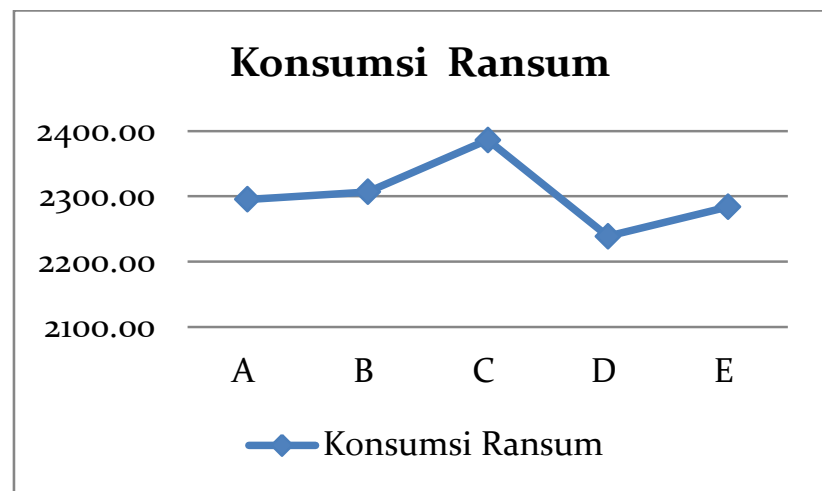

Gambar 1. Grafik konsumsi ransum selama penelitian.

Hasil penelitian menunjukkan bahwa, pemberian ransum adukan dengan feed additive tepung daun pepaya $0,5 \%$ lebih banyak dikonsumsi ayam pedaging, yaitu 2306,56 gram/ekor selama pemeliharaan. Sedangkan konsumsi ransum yang paling sedikit adalah ransum adukan dengan feed additive tepung daun jambu biji $0,5 \%$ yaitu 2238,78 gram/ekor. Berdasarkan analisis keragaman perbedaan ini tidak berbeda nyata $(\mathrm{P}>0,05)$. Penambahan tepung daun pepaya sampai pada level $9 \%$ dapat menurunkan konsumsi ayam pedaging umur 28 hari [9].

Secara keseluruhan rata-rata konsumsi ransum ayam pedaging selama 30 hari berkisar antara 2238,78 gram/ekor sampai dengan 2386,31 gram/ekor. Konsumsi ransum penelitian ini lebih banyak dibandingkan dengan konsumsi ransum ayam pedaging dengan pemberian ekstrak daun miana dalam air minum ayam pedaging. Konsumsi ransum ayam pedaging selama 30 hari dengan Pemberian ekstrak daun Miana (Coleus atropurpureus, L) dalam air minum sampai dengan taraf $0,125 \%$ adalah 2058,6o - 2178,80 g/ekor[10]. Konsumsi ransum pada perlakuan yang menggunakan tepung daun miana $0,5 \%$ adalah 2283,85 gram/ekor. Perbedaan bentuk pemberian feed additive berupa tepung dan ekstrak serta kandungan nutrisi ransum menyebabkan terjadinya perbedaan jumlah konsumsi ransum.

\subsection{Pertambahan bobot badan}

Berdasarkan hasil analisis keragaman pada Tabel 2 diketahui bahwa pemberian tepung daun tanaman obat sebagai feed additive pada ransum tidak memberikan pengaruh yang berbeda nyata $(\mathrm{P}>\mathrm{O}, \mathrm{O}, 5)$ terhadap pertambahan bobot badan. Tidak berbeda nyata $(\mathrm{P}>0,05)$ pengaruh perlakuan terhadap pertambahan bobot badan karena konsumsi ransum juga tidak berbeda nyata. Pertambahan bobot badan dipengaruhi oleh konsumsi ransum dan kandungan nutrisi ransum. Penambahan $0,5 \%$ tepung daun tanaman obat ke dalam ransum tidak banyak mempengaruhi kandungan nutrisi ransum, karena tujuan penambahan $0,5 \%$ tepung daun tanaman obat dalam ransum adalah memanfaatkan zat aktif yang pada tepung daun tersebut untuk daya tahan tubuh, dan menghasilkan performa ayam pedaging yang baik.

Tabel 2, memperlihatkan bahwa pertambahan bobot badan ayam pedaging terendah diantara perlakuan lainnya adalah ransum tanpa pemberian tanaman obat, yaitu 1121,32 gram/ekor, sedangkan pertambahan bobot badan yang tinggi diperoleh pada perlakuan feed additive tanaman obat dari tepung daun miana yaitu 1204,53 gram/ekor. Pertambahan bobot badan ayam pedaging dengan perlakuan ransum tanpa penambahan tanaman obat sebagai feed additive memberikan hasil yang lebih rendah dibandingkan dengan pakan yang ditambahkan feed additive tanaman obat. Hal ini karena pada tepung daun salam, tepung daun pepaya, tepung daun jambu biji dan tepung daun miana terdapat senyawa aktif yang berperan sebagai antimikroba, antibakteri yang berfungsi untuk daya tahan tubuh. Grafik pertambahan bobot yang diberi tepung daun dalam ransum seperti yang terlihat pada Gambar 2.

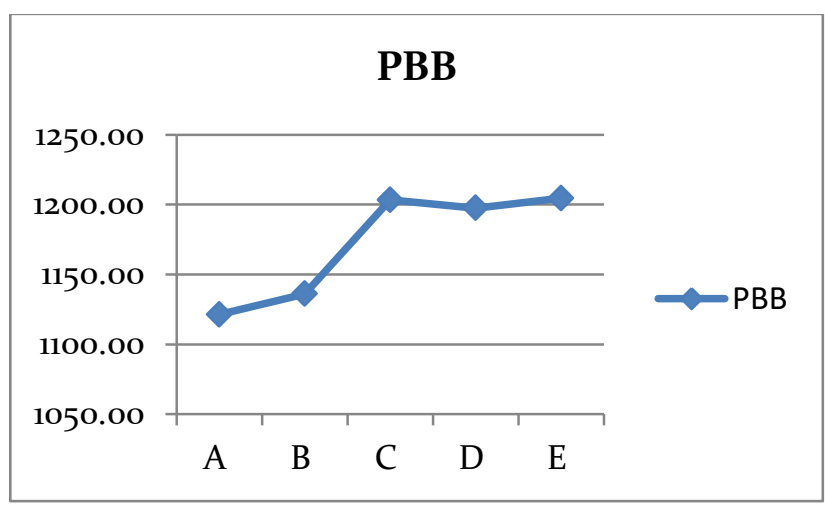

Gambar 2. Grafik Pertambahan bobot badan selama penelitian

Daun dari tanaman salam sudah dikenal oleh masyarakat sebagai bagian dari bumbu masakan dan obatan tradisional. Kandungan kimia dari tanaman salam berupa flavonoid, tannin, methyl chavicol dan minyak atsiri $0,2 \%$. Flavonoid adalah senyawa polifenol yang memiliki manfaat sebagai antivirus, antimikroba, antialergik, antiplatelet, antiinflamasi, antitumor, dan antioksidan sebagai sistem pertahanan tubuh [1].

Daun jambu biji mengandung senyawa antinutrisi berupa tannin. Namun kandungan tannin dengan konsentrasi yang rendah pada pakan masih menunjukkan pencernaan yang baik pada ayam. Hal ini dapat diketahui dari asupan pakan dan bobot 
badan yang diperoleh tidak memperlihatkan perbedaan secara signifikan [11]. Tanaman pepaya memiliki kandungan senyawa saponin, alkaloid, flavonoid, tannin, sistein proteinase, enzim papain, chymopapain, karpain dan ekstrak getah pepaya [12]. Aktivitas antibakteri dimiliki oleh senyawa alkaloid dari ekstrak etanol daun pepaya [3].

Senyawa aktif yang terdapat pada tiap-tiap tanaman obat ini tidak memberikan efek negatif terhadap pertumbuhan ayam pedaging. Hal ini dilihat dari pertambahan bobot badan ayam pedaging yang didapatkan tidak berbeda nyata $(\mathrm{P}>\mathrm{O}, 05)$ dengan ransum tanpa penambahan tanaman obat.

\subsection{Konversi ransum}

Berdasarkan hasil analisis keragaman pada Tabel 2 diketahui bahwa penambahan tepung daun tanaman obat sebagai feed additive pada ransum tidak memberikan pengaruh yang berbeda nyata $(\mathrm{P}>0,0,5)$ terhadap konversi ransum. Hal ini dikarenakan pemberian tanaman obat sebagai feed additive dalam ransum juga tidak memberikan pengaruh yang berbeda nyata terhadap konsumsi ransum dan pertambahan bobot badan. Konversi ransum didapatkan dari perbandingan jumlah ransum yang terkonsumsi dengan pertambahan bobot badan. Grafik pengaruh pemberian tepung daun terhadap konversi ransum selama penelitian seperti yang terlihat pada Gambar 3.

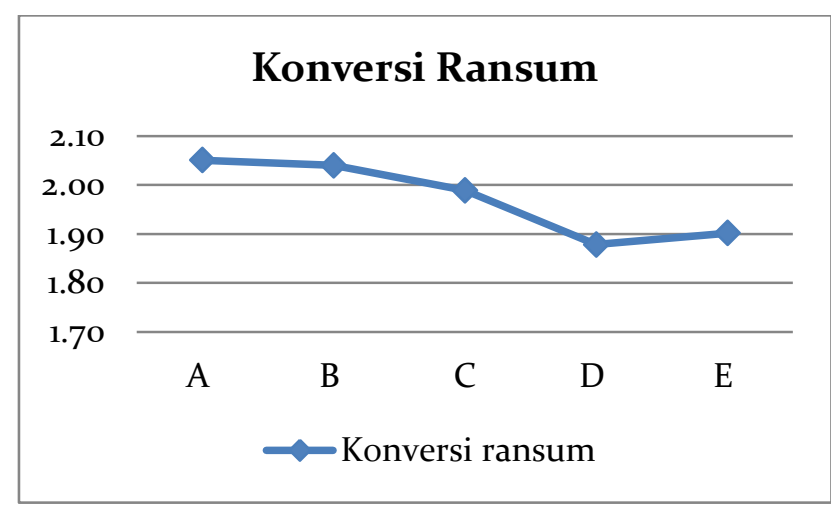

Gambar 3. Konversi ransum selama penelitian

Hasil penelitian didapatkan rata-rata nilai konversi ransum berkisar antara 1,87 sampai 2,05. Konversi ransum yang terendah dari hasil penelitian ini didapatkan dari penambahan tepung daun jambu biji sebanyak $0,5 \%$ dari jumlah ransum yaitu 1,87 . Semakin rendah nilai konversi ransum, maka akan semakin baik kualitas ransum tesebut. Konversi ransum merupakan total ransum yang dikonsumsi ternak untuk membentuk satu kilogram pertambahan bobot badan [13]. Nilai konversi ransum 2,05 pada penelitian ini didapatkan dari ransum yang dikonsumsi ayam pedaging tanpa penambahan tepung daun tanaman obat. Konversi ransum dengan additive tepung daun miana $0,5 \%$ adalah 1,90. Hasil ini sedikit lebih tinggi dibandingkan dengan hasil penelitian [14] didapatkan konversi ransum ayam pedaging dengan penggunan tepung daun miana $1 \%$ dalam ransum adalah 1,79. Semakin rendah nilai konversi ransum, menunjukkan semakin bagus kualitas ransum tersebut, artinya dengan sedikit ransum yang dikonsumsi akan didapatkan pertambahan bobot badan. Pada penelitian ini didapatkan bahwa penambahan tepung daun tanaman obat sebanyak $0,5 \%$ dalam ransum tidak memperlihatkan respon negatif terhadap performa ayam pedaging. Adanya kandungan senyawa aktif pada tepung daun salam, daun pepaya, daun jambu biji dan tepung daun miana memberikan nilai konversi ransum yang baik.

\subsection{Persentase bobot proventriculus}

Berdasarkan hasil analisis keragaman pada Tabel 2 diketahui bahwa penambahan tepung daun tanaman obat sebagai feed additive pada ransum tidak memberikan pengaruh yang berbeda nyata $(\mathrm{P}>\mathrm{O}, \mathrm{O}, 5)$ terhadap persentase bobot proventriculus. Grafik persentase bobot proventiculus yang didapatkan pada akhir penelitian seperti yang terlihat pada Gambar 4 . Tidak terdapatnya pengaruh yang berbeda nyata $(\mathrm{P}>0,05)$ dari perlakuan terhadap persentase bobot proventiculus karena penambahan tanaman obat berupa tepung daun dalam taraf yang rendah yaitu $0,5 \%$ dari jumlah ransum, sehingga memberikan pengaruh yang tidak besar terhadap kandungan nutrisi ransum. Tabel 1 memperlihatkan bahwa kandungan protein kasar ransum adalah 22,47\%, serat kasar 3,12\% dan lemak kasar 3,94\%. Kandungan nutrisi ransum ini telah memenuhi kebutuhan nutrisi ayam pedaging, sehingga tidak memberikan pengaruh yang sangat besar terhadap organ pencernaan. Hasil penelitian [15] dihasilkan bahwa kandungan serat kasar memberikan pengaruh terhadap kecernaan ransum, sehingga kandungan serat kasar yang tinggi dapat menyebabkan organ pada saluran pencernaan bekerja lebih berat dan mengakibatkan peningkatan ukuran dari organ saluran pencernaan. Hasil penelitian [16], didapatkan persentase bobot proventriculus dari bobot hidup ayam pedaging dengan suplementasi sampai dengan $12 \%$ daun papaya dalam ransum komersial yaitu $0,31 \%-0,40 \%$. Hasil penelitian tersebut lebih rendah dibandingkan dengan persentase bobot proventriculus dengan penambahan tepung daun tanaman obat pada ransum adukan, yaitu $0,511 \%$ o,664\%. 


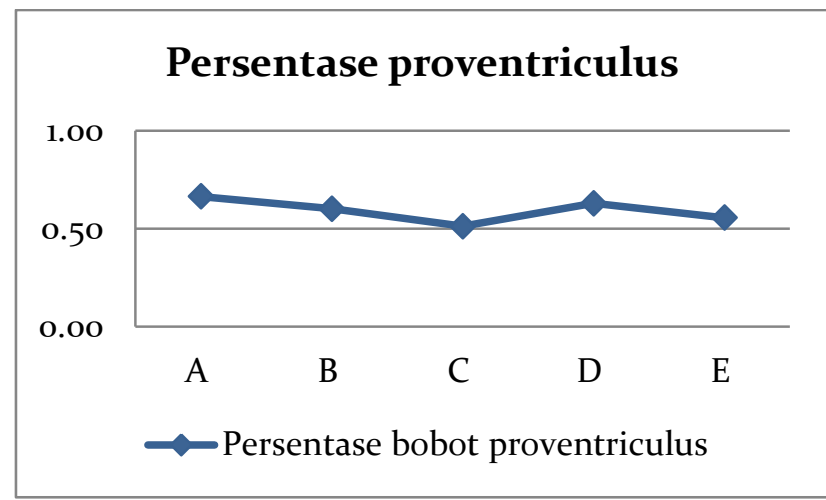

Gambar 4. Persentase bobot proventriculus

\subsection{Persentase bobot ventriculus}

Berdasarkan hasil analisis keragaman pada Tabel 2 diketahui bahwa penambahan tepung daun tanaman obat sebagai feed additive pada ransum juga tidak memberikan pengaruh yang berbeda nyata $(\mathrm{P}>0,0,5)$ terhadap persentase bobot ventriculus. Grafik dari pengaruh pemberian tepung daun terhadap persentase bobot ventriculus seperti yang terlihat pada Gambar 5. Rata-rata persentase bobot ventriculus yang didapatkan pada akhir penelitian adalah 1,779\% - 2,181\% dari bobot hidup. Persentase bobot ventriculus ini tidak jauh berbeda dengan hasil penelitian [15], bahwa penggunaan daun murbey sampai dengan $\mathbf{2 0} \%$ dalam ransum didapatkan persentase bobot venticulus adalah 1,82\% - 2,22\%. Tidak berbeda nyata $(\mathrm{P}>0,05)$ perlakuan tepung daun tanaman obat terhadap persentase bobot ventriculus karena konsumsi ransum yang juga tidak berbeda nyata $(\mathrm{P}>0,05)$. Ventriculus merupakan organ pencernaan yang bekerja mencerna ransum secara mekanik yaitu menghaluskan partikel pakan yang masuk. Semakin banyak ransum yang dikonsumsi akan semakin banyak kerja ventriculus dalam proses pencernaan. Lebih lanjut dinyatakan bahwa bahwa jumlah ransum yang dikonsumsi, bentuk ransum dan ukuran ternak akan mempengaruhi ukuran ventriculus [17].

Penambahan tepung daun sebanyak o,5\% pada ransum tidak menyebabkan kandungan nutrisi mengalami perbedaan penurunan ataupun peningkatan yang banyak. Bila dilihat kandungan serat kasar ransum berkisar 3,12\%, masih dalam taraf yang dapat ditolerir dalam pencernaan ayam pedaging. Hasil penelitian dengan ransum berserat kasar 4\%, 6\%, 8\% dan $10 \%$, didapatkan bahwa persentase bobot gizzard atau ventriculus adalah 4,57\%, 3,70\% 4,01\% dan 3,39\%. Sehingga dinyatakan bahwa level pemberian serat kasar hingga 10\% tidak memberikan dampak yang signifikan terhadap persentase gizzard dari ayam jantan tipe medium umur 8 minggu dan masih mampu dicerna oleh gizzard [18].

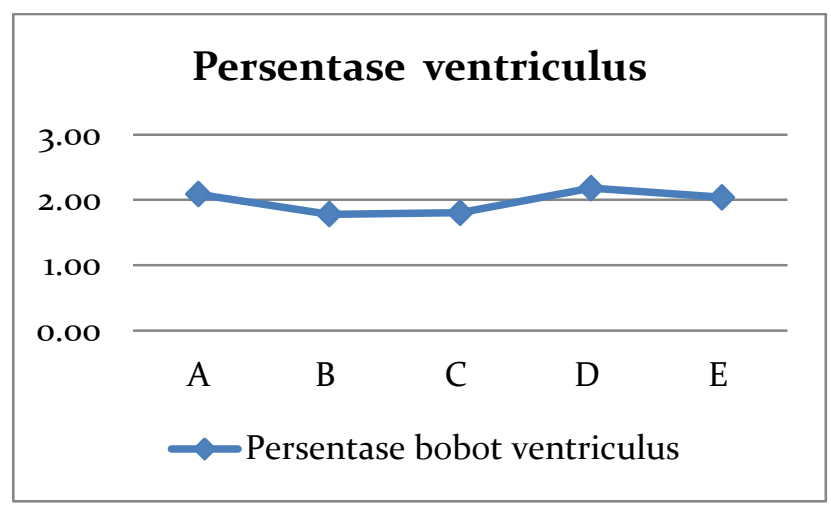

Gambar 5. Persentase bobot ventriculus

\section{Kesimpulan}

Penggunaan tanaman obat sebanyak o,5\% sebagai feed additive dalam ransum berupa tepung daun salam, daun jambu biji, daun pepaya dan tepung daun miana tidak memberikan pengaruh yang berbeda nyata terhadap performa ayam pedaging dan persentase bobot organ pencernaan serta tidak memberikan efek yang negatif.

\section{Referensi}

[1] Harismah, $\mathrm{K}$ and Chusniatun, "Pemanfaatan Daun Salam (Eugenia Polyantha) Sebagai Obat Herbal Dan Rempah Penyedap Makanan," War. LPM, Vol. 19, No. 2, Pp. 110-118, 2016.

[2] K. G. Wiryawan, S. Luvianti, W. and Hermana, And S. Suharti, "Peningkatan Performa Ayam Ayam pedaging Dengan Suplementasi Daun Salam Syzygium Polyanthum (Wight) Walp Sebagai Antibakteri Escherichia Coli," Media Peternak., Vol. 30, No. 1, Pp. 55-62, 2007.

[3] N. K. Jati, A. T. Prasetya, and S. Mursiti, "Isolasi, Identifikasi, Dan Uji Aktivitas Antibakteri Senyawa Alkaloid Pada Daun Pepaya," J. Mipa, Vol. 42, No. 1, Pp. 1-6, 2019.

[4] S. Indriani, "Aktivitas Antioksidan Ekstrak Daun Jambu Biji (Psidium Quajava, L)," J.Ii. Pert. Indon, Vol. 11, No. 1, Pp. 13-17, 2006, Doi: 10.16309/J.Cnki.Issn.1007-1776.2003.03.004.

[5] A. Z. Wakhidah and M. Silalahi, "Etnofarmakologi Tumbahan Miana (Coleus Scutellariodes (L.) Benth) Pada Masyarakat Halmahera Barat, Maluku Utara," J. Pro-Life., Vol. 5, No. 2, Pp. 567-578, 2018.

[6] R. G. D. And Steel and J. H. Torries., Principles And Procedures Of Statistic, A Biometrical Aproach., 2nd Ed. 1993.

[7] J. Wahju, Ilmu Nutrisi Unggas. Gadjah Mada University Press, 2015.

[8] E. Widodo, O. Sjofjan, and A. Z. Wijaya, "Limbah Mie Sebagai Pengganti Jagung Dalam Pakan Ayam Pedaging Dan Pengaruhnya Terhadap Kualitas Pakan," Ilmu Dan Teknol. Has. Ternak, Vol. 5, No. 1, Pp. 38-46, 2010.

[9] Y. Sari, E. Erwan, and E. Irawati, "Inclusion 
Different Level Of Papaya Leaves Meal (Carica Papaya L.) In Pellet Ration On Performance In Ayam pedaging Chickens," Iop Conf. Ser. Earth Environ. Sci., Vol. 515, No. 1, 2020, Doi: 10.1088/1755-1315/515/1/012001.

[10] N. Fati, D. Syukriani, U. Mohtar Lutfi, and R. Siregar, "Pengaruh Pemberian Ekstrak Daun Miana (Coleus Atropurpureus, L ) Dalam Air Minum Terhadap Performa Ayam pedaging," Vol. 23, Pp. 1-15, 2020.

[11] H. Setiawan, L. B. Utami, and M. Zulfikar, "Serbuk Daun Jambu Biji Memperbaiki Performans Pertumbuhan Dan Morfologi Duodenum Ayam Jawa Super," J. Vet., Vol. 19, No. 4, Pp. 554-562, 2018, Doi: 10.19087/Jveteriner.2018.19.4.554.

[12] L. A. Oktofani and J. F. Suwandi, "Potensi Tanaman Pepaya (Carica Papaya L.) Sebagai Antihelmintik," Majority, Vol. 8, No. 1, Pp. 246250, 2019.

[13] E. Supriyatna, U. Atmomarsono, and R. Kartasudjana, Ilmu Dasar Ternak Unggas. Penebar Swadaya, Jakarta, 2005.

[14] N. Fati, R. Siregar, U. . Lutfi, D. Syukriani, And T. Malvin, "Ayam pedaging Response On Increase In Flour Leaves Miana (Coleus Atropurpureus, L) As A Feed Aditive In Ration," Eksakta Berk. Ilm. Bid. Mipa, Vol. 20, No. 2, Pp. 52-61, 2019, Doi: 10.24036/Eksakta/Vol2o-Iss2/203.

[15] H. Has, A. Napirah, and A. Indi, "Efek Peningkatan Serat Kasar Dengan Penggunaan Daun Murbei Dalam Ransum Ayam pedaging Terhadap Persentase Bobot Saluran Pencernaan. Jitro, Vol. 1, No. 1, Pp. 63-69, 2014.

[16] Afriadi; and R. Zurina, "Pengaruh Penambahan Daun Pepaya (Carica Pepaya) Dalam Ransum Sebagai Suplemen Terhadap Persentase Karkas, Lemak Abdomen Dan Organ Dalam Ayam Ayam pedaging," Pp. 77-82, 2016.

[17] M. C. Simanjuntak and P. Patabo, "Pengaruh Pemberian Tepung Daun Sirsak (Annona Muricata L.) Dalam Pakan Terhadap Organ Dalam Ayam Pedaging (Ayam pedaging)," J. Agroforestri, Vol. Xi, No. 1, Pp. 57-68, 2016.

[18] G. G. Maradon, R. Sutrisna, And Erwanto, "Pengaruh Ransum Dengan Kadar Serat Kasar Berbeda Terhadap Organ Dalam Ayam Jantan Tipe Medium Umur 8 Minggu," J. Ilm. Peternak. Terpadu, Vol. 3, No. 2, Pp. 6-11, 2015. 